\title{
Effect of Ghilling on Aerobacter aerogenes in Aqueous Suspension
}

\author{
By R. E. STRANGE AND F. A. DARK \\ Microbiological Research Establishment, Porton, near Salisbury, Wilts.
}

(Received 13 April 1962)

\begin{abstract}
SUMMARY
The lethal effect of cold shock on Aerobacter aerogenes suspensions depended on the time of exposure to low temperature, the growth phase, the concentration of bacteria, the diluent. No death occurred when weak suspensions of susceptible bacteria (about $10^{8} / \mathrm{ml}$.) in buffered saline $(\mathrm{pH} \mathrm{6.5}$ ) were rapidly cooled to $0^{\circ}$ and immediately warmed to $20^{\circ}$, but loss of viability was progressive during $1 \mathrm{hr}$. at $0^{\circ}$. Bacteria harvested from defined medium at intervals during the exponential growth phase varied in sensitivity to chilling but were more susceptible than stationary phase organisms. While growing in partially synchronized culture the sensitivity of bacteria did not increase significantly during the division lag phase. The viability of dense suspensions (about $10^{10}$ bacteria/ml.) in buffered saline was little affected by chilling for $1 \mathrm{hr}$. at $0^{\circ}$, irrespective of the growth phase. A bacteria-free filtrate from a chilled concentrated suspension of exponential-phase organisms substantially protected a dilute suspension from the lethal effect of chilling. Substances found in protective filtrates were amino acids, adenosine triphosphate and nucleic acid constituents. When added to the diluent in which susceptible bacteria were chilled, a mixture of amino acids afforded some protection; small amounts of adenosine triphosphate had no effect. Other substances found to protect susceptible bacteria were sucrose $(0.3 \mathrm{M})$, magnesium or calcium ions $\left(5 \times 10^{-3} \mathrm{M}\right)$ and, to a much smaller extent, spermine $\left(10^{-5} \mathrm{M}\right)$. The present results support the suggestion that the lethal effect of chilling is at least partly due to interference with the functioning of a bacterial permeability control mechanism.
\end{abstract}

\section{INTRODUCTION}

Sudden chilling causes loss of viability of suspensions of exponential phase Escherichia coli (Sherman \& Albus, 1923; Sherman \& Cameron, 1934; Hegarty \& Weeks, 1940; Meynell, 1958) and Pseudomonas pyocyanea (Gorrill \& McNeil, 1960). Meynell (1958) showed that the lethal effect was not due to sudden cooling in itself by demonstrating that survival was complete either after gradual cooling in a potentially lethal diluent or after sudden chilling in a solution of sucrose $(0 \cdot 3 \mathrm{M})$. He suggested the lethal effect may be due to interference with an adaptive mechanism which prevents entry of water into the organism and that the mechanism has negligible activity at $4^{\circ}$. Bacterial death following chilling was not accompanied by lysis and Meynell detected no differences between electron micrographs of chilled and unchilled bacteria from the same culture. Gorrill \& McNeil (1960) could not distinguish morphological differences between cold shocked and unshocked $P$. pyo- 
cyanea with either dark-ground, phase-contrast or ordinary light microscopy. The present paper records a study of cold shock in Aerobacter aerogenes.

\section{METHODS}

Aerobacter aerogenes strain NCTC 418 was obtained from Professor Sir Cyril Hinshelwood's laboratory.

Medium and cultural conditions. Organisms were grown at $37^{\circ}$ and at a continuously maintained $\mathrm{pH}$ value of $\mathbf{7 \cdot 2 - 7 \cdot 4}$ with adequate aeration in a batch culture vessel containing the defined carbon-limiting medium previously described (Strange, Dark \& Ness, 1961). Partially synchronized cultures were obtained by depriving organisms of an energy source for a period before growth (McNair Scott \& Chu, 1958): medium was seeded with a suspension of washed stationary-phase bacteria which had been held in buffered saline (pH 6.5) for $20 \mathrm{hr}$. at $37^{\circ}$ with aeration.

Viability determinations. The direct determination of the percentage viable bacteria in a suspension by a slide culture method (Postgate, Crumpton \& Hunter, 1961) and counts of viable bacteria, were made as previously described (Strange et al. 1961).

Chilling. Bacteria were usually separated from the culture by centrifugation and resuspended at a suitable concentration in the same diluent as that in which they were subsequently chilled. With experiments shown in Figs. 1 and 3, culture directly from the growth vessel was used. Rapid cooling of bacterial suspensions was achieved by dilution (1/50-1/100) in cold diluent held in a temperaturecontrolled bath containing aqueous ethylene glycol at $0^{\circ}$. Concentrated bacterial suspensions were initially cooled to near $0^{\circ}$ by contact with brine at $-10^{\circ}$ before placing in the bath. When freezing occurred during cooling, the suspension was discarded. The diluents used were buffered saline which contained: $\mathrm{NaCl}(0 \cdot 13 \mathrm{M})$ and appropriate concentrations of $\mathrm{K}_{2} \mathrm{HPO}_{4}+\mathrm{KH}_{2} \mathrm{PO}_{4}\left(0.02 \mathrm{M} \mathrm{PO}_{4}\right)$ to give the required $\mathrm{pH}$ value; $0.05-0.15 \mathrm{M}$ 2-amino-2(hydroxymethyl)-1:3-propanediol(tris) $+\mathrm{HCl}$ to give the required $\mathrm{pH}$ value (tris buffer); distilled water. All diluents and diluents + additives were filtered through a well-washed filter membrane before use.

Materials. Distilled water was passed through a mixed-bed ion-exchange resin (Amberlite MB-1 from British Drug Houses Ltd.) column before use. Whenever possible, Analytical Reagent Grade substances were used. Hydrated disodium adenosine-5-triphosphate (ATP) was obtained from Sigma Chemical Co., St Louis, Missouri, U.S.A.; dehydrated firefly tails were obtained from L. Light \& Co. Ltd.; Oxoid filter membranes, grade A.P., from Oxo Ltd.

Analytical Methods. The total amino acid content of samples was determined by a ninhydrin colorimetric method (Yemm \& Cocking, 1955) with alanine as the standard. Amino acids were identified by 2-dimensional paper chromatography with phenol saturated with water in an atmosphere of $\mathrm{NH}_{3}$ as first solvent, butanol+ acetic acid + water $(40+10+50$, by vol.; upper phase) as second solvent and ninhydrin as the spray reagent. ATP was determined by the following firefly luminescence technique which is essentially that described by Strehler \& Totter (1952): reaction mixtures $(4 \mathrm{ml}$.) contained $0.02 \mathrm{M}$ sodium arsenate buffer $(\mathrm{pH} 7 \cdot 4), 3 \mathrm{~mm}-$ $\mathrm{Mg}^{2+}, 0-0 \cdot 2 \mu \mathrm{g}$. ATP and enzyme extracted from $2 \cdot 5 \mathrm{mg}$. firefly tails; at the addition of enzyme, a stop-watch was started and luminescence was measured for $0.5 \mathrm{~min}$. (beginning $1 \mathrm{~min}$. after mixing) with a scintillation counter constructed by 


\section{Effect of chilling on Aerobacter aerogenes}

our colleague Mr S. Lovett. During a series of ATP determinations, counts were obtained for appropriate blank and standard mixtures at regular intervals. Magnesium was determined by the Eriochrome Black $\mathrm{T}$ colorimetric procedure (Levine \& Cummings, 1956) and calcium was detected by precipitation as the oxalate. Ultraviolet (u.v.) absorption was measured in a Unicam quartz spectrophotometer, model S.P. 500, with a $1 \mathrm{~cm}$. light path. Bacterial dry weights were determined as previously described (Strange et al. 1961).

\section{RESULTS}

\section{Influence of bacterial growth phase on the lethal effect of chilling}

Figure 1 shows a typical growth curve for Aerobacter aerogenes in defined medium and the sensitivity to chilling of bacteria harvested at intervals during the growth period. Exponential-phase organisms were most sensitive to chilling after growth for about $132 \mathrm{~min}$. and then became progressively less sensitive up to $168 \mathrm{~min}$. before division ceased. Differences in the sensitivity of Escherichia coli to chilling during exponential growth were reported by Hegarty \& Weeks (1940) and Meynell (1958; Fig. 1). Loss of viability of susceptible bacterial suspensions held at $0^{\circ}$ was progressive and bacteria removed immediately after chilling were completely viable. Figure 2 shows survival curves for bacteria harvested at four different times during the growth period and then held at $0^{\circ}$. The susceptibility to chilling of bacteria in different stages of the division cycle was examined by means of a partially synchronized culture (Fig. 3). During the initial lag phase, the bacteria became almost completely resistant to chilling but sensitivity increased immediately division began. In this and other experiments resistance to chilling during the first division lag period (i.e. when organisms were increasing in size before the second division) did not increase to that of stationary phase or initial lag-phase bacteria, but remained unchanged or increased only slightly before decreasing during the second division (Fig. 3). It is of interest that, whereas freshly harvested stationaryphase organisms were relatively resistant to chilling, after storage for $20 \mathrm{hr}$. at $37^{\circ}$ in buffered saline with aeration their resistance decreased and was little higher than that of exponential-phase bacteria (Fig. $3, t=0$ ).

\section{Effect of the diluent}

In the experiments above the ionic strength of buffered saline used as a diluent was similar to that of 'physiological saline' $(\mathrm{NaCl}, 0.9 \%, \mathrm{w} / \mathrm{v})$. When similar concentrations of the same batch of exponential-phase organisms were chilled in this and other diluents, the losses of viability shown in Table 1 were obtained. In several experiments, losses were higher in tris buffer than in the other diluents. The high loss of viability occurring in this diluent during chilling was not due to contamination of tris salt by heavy metals since the addition of disodium ethylenediamine tetraacetic acid (EDTA; $0.32 \mathrm{~mm}$ ) to tris buffer had no effect on the results. Of these diluents, distilled water was usually the least toxic but with a few batches of organisms a slightly greater loss of viability occurred on chilling in water than in buffered saline.

Loss of viability of bacterial suspensions held at $0^{\circ}$ occurred progressively with time (Fig. 2) and it was of interest to determine whether sudden warming after a 
period at $0^{\circ}$ decreased the rate of viability loss. A suspension of washed exponentialphase organisms in buffered saline $\left(\mathrm{pH} \mathrm{6.5)}\right.$ was cooled to $0^{\circ}$ and samples, removed immediately and at intervals, were rapidly warmed to $18^{\circ}$ in a water bath. Chilling

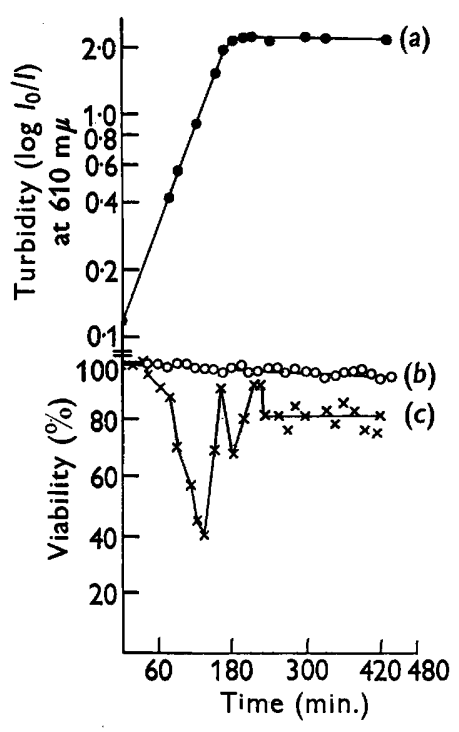

Fig. 1

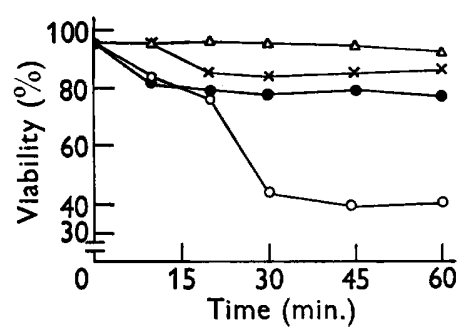

Fig. 2

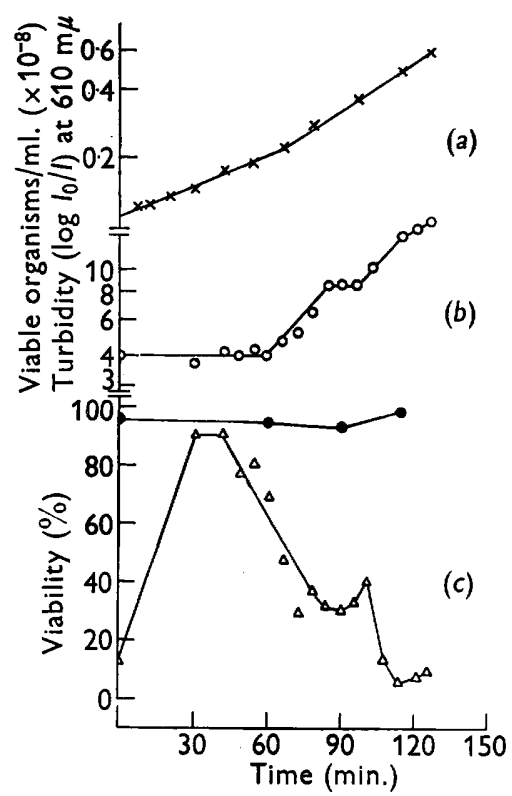

Fig. 3

Fig. 1. Effect of growth phase on susceptibility of Aerobacter aerogenes to cold shock. (a) Growth curve in carbon-limiting mannitol+salts medium. (b) Viabilities of samples $30 \mathrm{~min}$. after dilution to about $10^{8}$ bacteria $/ \mathrm{ml}$. in buffered saline held at $20^{\circ}$. (c) Viabilities after a similar period at $0^{\circ}$.

Fig. 2. Survival of exponential and stationary phase Aerobacter aerogenes at $0^{\circ}$. Bacteria were separated from the culture by centrifugation and diluted to about $10^{8} / \mathrm{ml}$. in buffered saline at $0^{\circ}$. Exponential phase organisms $(O)$; bacteria in the stationary phase for $15 \mathrm{~min} .(\bullet), 75 \mathrm{~min} .(\times)$, and $135 \mathrm{~min} .(\triangle)$.

Fig. 3. Susceptibility of Aerobacter aerogenes to cold shock during partially synchronous growth. (a) Growth curve in defined carbon-limiting medium determined by viable counts $(O)$ and turbidity $(x)$. (b) Viabilities of samples $30 \mathrm{~min}$. after dilution to about $10^{8} \mathrm{bacteria} / \mathrm{ml}$. in buffered saline at $20^{\circ}$. (c) Viabilities after a similar period at $0^{\circ}$.

followed immediately by warming had no effect on viability, whereas after chilling for $5 \mathrm{~min}$. or more, suspensions continued to lose viability at $18^{\circ}$ but at a slower rate than at $0^{\circ}$ (Fig. 4 ). 


\section{Influence of bacterial concentration}

Five suspensions containing different concentrations of a batch of exponentialphase organisms in buffered saline were held at $0^{\circ}$ for $1 \mathrm{hr}$. Survival curves showed that the death rate was greater the sparser the population (Fig. 5). A similar but less pronounced phenomenon occurred in tris buffer: suspensions of $5 \times 10^{7}, 10^{9}$ and $10^{10}$ viable bacteria/ml. tris buffer had viabilities of 8,57 and $96 \%$ respectively, immediately after chilling, and 8,5 and $53 \%$ respectively, after $1 \mathrm{hr}$. at $0^{\circ}$.

In the case of concentrated exponential-phase suspensions, it seemed possible that the relatively great resistance to chilling was due to the appearance in the suspending fluid of material with protective activity. To examine this possibility,

Table 1. Effect of the diluent on the loss of viability of exponential phase Aerobacter aerogenes held at $0^{\circ}$ and $20^{\circ}$

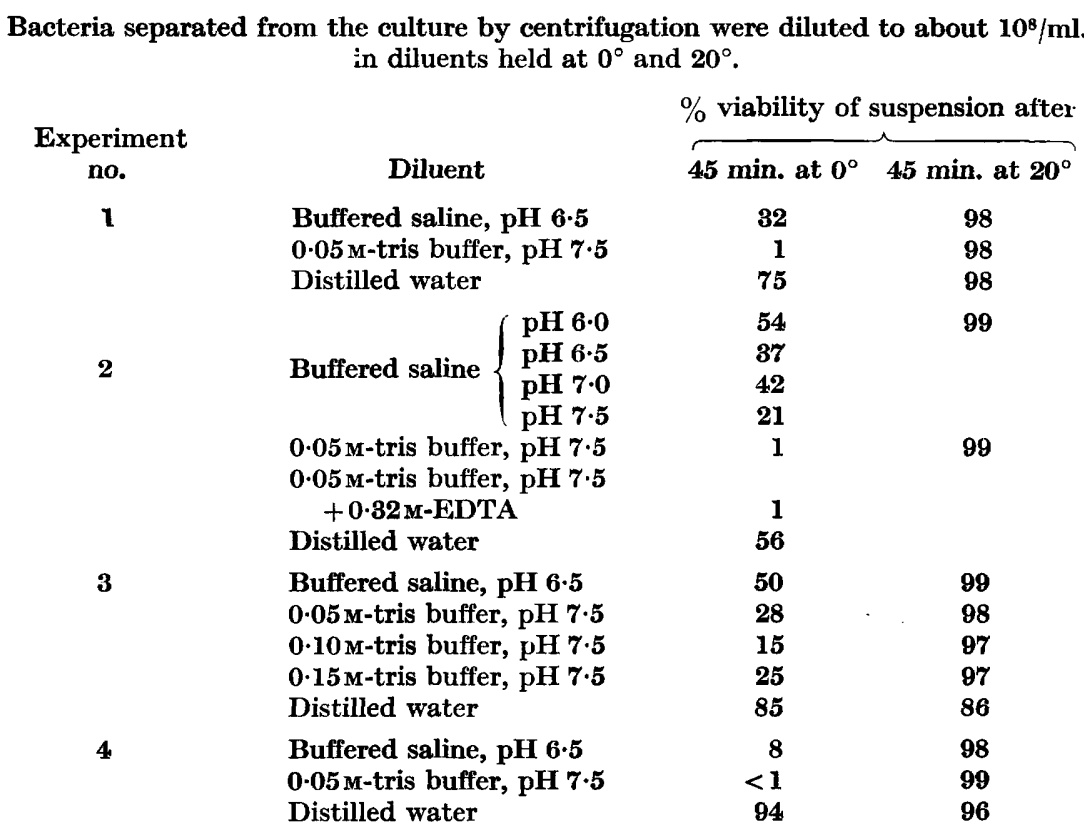

supernatant liquid separated from a chilled $\left(1 \mathrm{hr}, 0^{\circ}\right)$ suspension initially containing $1.3 \times 10^{10}$ viable exponential-phase bacteria $/ \mathrm{ml}$. buffered saline was passed through a filter membrane and tested as follows: tubes containing $(a)$ filtrate, $(b)$ filtrate + 3 vol. buffered saline, $(c)$ buffered saline, were cooled and sufficient fresh suspension was added to give about $10^{8}$ organisms $/ \mathrm{ml}$. each diluent. After $45 \mathrm{~min}$. at $0^{\circ}$, the viabilities of $(a),(b)$ and $(c)$ were 99,94 and $23 \%$, respectively. When filtrates from chilled $\left(1 \mathrm{hr} ., 0^{\circ}\right)$ exponential- and stationary-phase bacterial suspensions of about the same concentration $\left(10^{10}\right.$ bacteria $/ \mathrm{ml}$.) were tested in a similar manner, viabilities after $45 \mathrm{~min}$. at $0^{\circ}$ were 98 and $64 \%$, respectively, as compared with $24 \%$ in the buffered saline control. The activity of protective material present in filtrates was not affected by heating for $15 \mathrm{~min}$. at $100^{\circ}$. These and other experiments showed that filtrate from chilled exponential-phase bacteria and, to a lesser extent, 
from chilled stationary-phase organisms, contained substances which protected exponential-phase Aerobacter aerogenes from the lethal effect of chilling.

\section{Examination of leakage products from chilled bacteria}

The identification of the protective material present in filtrates from chilled bacterial suspensions was complicated by the fact that the time taken to prepare the relatively concentrated suspensions required for analytical investigation was

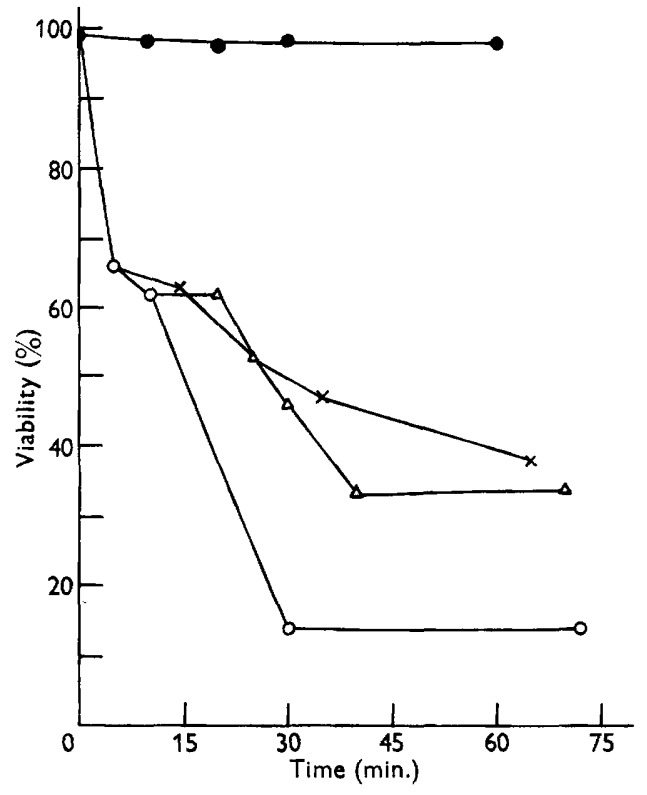

Fig. 4

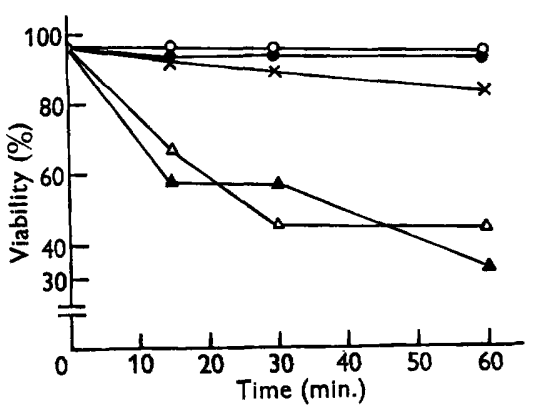

Fig. 5

Fig. 4. Survival of exponential phase Aerobacter aerogenes chilled at $0^{\circ}$ for short periods and then held at $18^{\circ}$. Bacterial suspensions were prepared as in Fig. 2. Viability at $18^{\circ}$ immediately after chilling (O), after chilling for $5 \mathrm{~min} .(x)$ and after chilling for $10 \mathrm{~min}$. $(\triangle)$; viability of control suspension held throughout at $0^{\circ}(O)$.

Fig. 5. Effect of population density on the survival of exponential phase Aerobacter aerogenes at $0^{\circ}$. Bacteria, separated from the culture by centrifugation, were resuspended at different concentrations in buffered saline held at $0^{\circ}$. Viabilities immediately and at intervals after chilling of suspensions initially containing: $6 \times 10^{7}(\Delta), 1.2 \times 10^{8}(\triangle)$, $1.2 \times 10^{9}(\times), 2.4 \times 10^{9}(0), 1.2 \times 10^{10}(O)$ viable bacteria $/ \mathrm{ml}$.

sufficient to affect the sensitivity of bacteria to chilling. For example, a suspension diluted and chilled $10 \mathrm{~min}$. after the bacteria were harvested lost $60 \%$ viability in $45 \mathrm{~min}$. at $0^{\circ}$ as compared with $10 \%$ when the suspension was held for $45 \mathrm{~min}$. at $20^{\circ}$ before chilling for the same period. The problem could not be resolved by direct chilling of the culture because medium constituents and growth products interfered with subsequent analysis. In the experiments described, suspensions were chilled 15-20 min. after harvesting the organisms. Bacteria, separated from an exponentialphase culture by filtration through filter membrane, were washed several times on the pad with buffered saline and resuspended at a concentration of $3.2 \times 10^{9}$ viable bacteria $/ \mathrm{ml}$. (99\% viable). Part of the suspension was rapidly cooled to $0^{\circ}$ and the 
remainder held at $20^{\circ}$. Samples were taken immediately and at intervals from each suspension for viability determinations and analyses. The latter samples were immediately freed from bacteria by filtration (filter membrane) and the filtrates analysed for ninhydrin-reacting substances and ATP. The concentration of ninhydrin-reacting substances in filtrates was expressed as percentage total amino acids (as alanine) extractable with cold $0.5 \mathrm{~N}-\mathrm{HClO}_{4}$ from an equal volume of whole bacterial suspension. Cooled suspension ( $4 \mathrm{ml}$.) was acidified by the addition of $\mathrm{HClO}_{4}\left(72 \% ; 0.17 \mathrm{ml}\right.$.) and left for $30 \mathrm{~min}$. at $0^{\circ}$. After centrifugation, the supernatant fluid was neutralized with $2 \mathrm{~N}-\mathrm{KOH}$, filtered through a membrane filter and analysed for amino acids. Total amino acids (as alanine) in exponential phase Aerobacter aerogenes suspensions accounted for about $1 \%$ of the bacterial dry weight. The results (Fig. 6) showed that the chilled suspension progressively lost viability, whereas the unchilled suspension remained completely viable, and the leakage of ninhydrin-reacting substances and also of ATP was greater from chilled bacteria. Paper chromatographic examination of similar filtrates obtained from more concentrated bacterial suspensions showed that the ninhydrin-reacting material could be largely accounted for as free amino acids and peptides of relatively small molecular weight. After electrolytic desalting and concentration, filtrate from a chilled suspension $\left(1 \mathrm{hr} ., 0^{\circ}\right.$ ) gave spots corresponding in position to aspartic acid, glutamic acid, glycine, serine, alanine, methionine, valine, leucine, arginine and histidine, with at least two unidentified components; acid hydrolysis of the filtrate $\left(6 \mathrm{~N}-\mathrm{HCl}, 20 \mathrm{hr} ., 106^{\circ}\right)$ caused an increase in intensity of several spots, the disappearance of two unidentified constituents and the appearance of several other common amino acid spots. Paper chromatograms of filtrate from suspensions of similar concentration held for the same period at $20^{\circ}$ showed the presence of several amino acids but in much lower concentrations than those found with chilled suspensions. Neither acid-insoluble protein nor ribonucleic acid (RNA) were detected as constituents of the material which leaked from chilled bacteria. For example, filtrate from a chilled exponential-phase suspension of organisms equivalent to $26 \mathrm{mg}$. dry weight $/ \mathrm{ml}$. (about $5 \times 10^{10}$ bacteria $/ \mathrm{ml}$.) gave no turbidity with $\mathrm{HClO}_{4}(0.5 \mathrm{~N})$ under conditions where protein or RNA equivalent to $0.04 \%$ bacterial dry weight would have been detected. Although acid-insoluble RNA was absent, filtrates from chilled and unchilled bacterial suspensions contained u.v.absorbing substances in greater concentration than could be accounted for by ATP. Maximum absorption occurred at a wavelength near $260 \mathrm{~m} \mu$ and the initial rate of leakage of these substances was much greater from chilled than from unchilled organisms (Fig. 7). However, on storage of suspensions for longer periods at $20^{\circ}$ the u.v.-absorption of the suspending liquid increased steadily, whereas at $0^{\circ}$ it reached a maximum after about $30 \mathrm{~min}$. and then remained unchanged. This was due to metabolism of endogenous RNA which occurs in starved Aerobacter aerogenes suspensions held at $20^{\circ}$, resulting in the excretion of nucleic acid bases (Strange $e$ al. 1961), whereas at $0^{\circ}$, negligible degradation of RNA was found to occur. Neither magnesium nor calcium ions were found in protective filtrates under conditions where $0.5 \mathrm{~mm}$ of either would have been detected. 


\section{Protective effect of exogenous substances}

The possibility that the protective effect of leakage products from chilled organisms was due to the presence of ATP or amino acids was investigated. Also, the influence during cold shock of various other substances, not detected in leakage products, was examined.

$A T P$. The addition of ATP at a concentration similar to that found in protective filtrates (10-20 $\mu \mathrm{M})$ to buffered saline or tris buffer diluents afforded no protection to exponential phase organisms against cold shock.

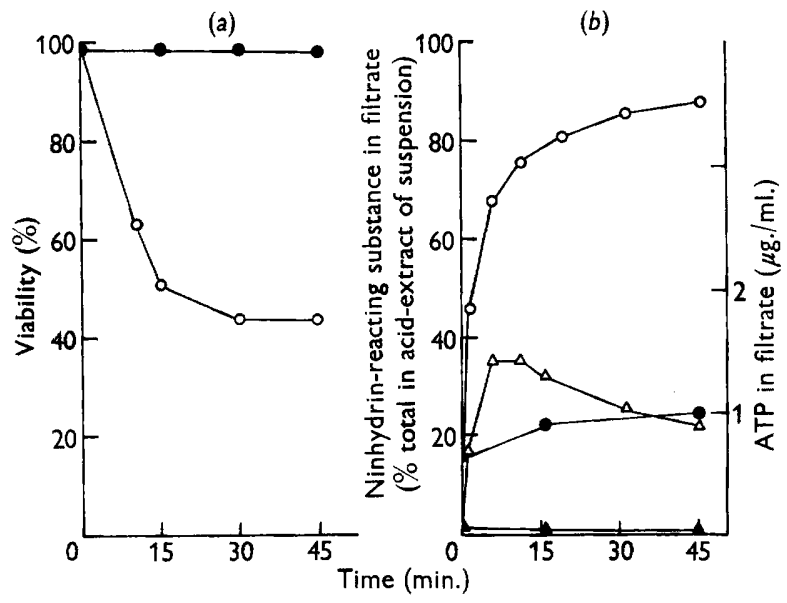

Fig. 6

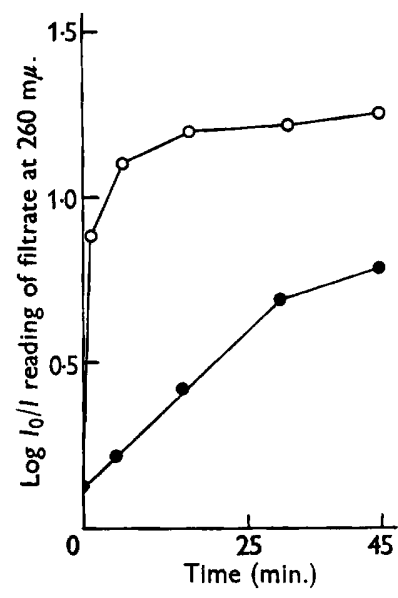

Fig. 7

Fig. 6. Leakage of endogenous constituents from exponential phase Aerobacter aerogenes held in suspension at $0^{\circ}$ and $20^{\circ}$. Washed organisms were resuspended in buffered saline (equiv. 2.1 mg. bacterial dry weight $/ \mathrm{ml}$.). (a) Loss of viability at $0^{\circ}(O)$ and $20^{\circ}(O)$. (b) Concentration of ninhydrin-reacting substances as alanine (percentage total cold acid-extractable amino acids in whole suspension) in filtrate from suspension at $0^{\circ}(O)$ and $20^{\circ}(\odot)$; ATP $(\mu \mathrm{g} . / \mathrm{ml}$.$) in filtrate from suspension at 0^{\circ}(\Delta)$ and at $20^{\circ}(\Delta)$.

Fig. 7. Leakage of u.v.-absorbing substances from exponential Aerobacter aerogenes held in suspension at $0^{\circ}$ and $20^{\circ}$. Bacterial suspension (equiv, 2.6 mg. bacterial dry weight/ ml.) was prepared as in Fig. 6. Spectrophotometric measurements at $260 \mathrm{~m} \mu$ on filtrate from suspension at $0^{\circ}(O)$ and $20^{\circ}(O)$.

Amino acids. Loss of viability of bacteria chilled in buffered saline containing the 10 amino acids detected in leakage products (each $0.5 \mathrm{~mm}$ ) occurred at a slower rate than in buffered saline alone (Fig. 8). The addition of 7 other amino acids (each $0.5 \mathrm{~mm}$ ) to this mixture did not improve the protection afforded and neither mixture was as effective as leakage products (Fig. 8). The influence of the 17 amino acid mixture was similar after fivefold dilution with buffered saline, but below this concentration the protective effect disappeared.

Divalent metal ions. The leakage of endogenous constituents which occurred as a result of cold shock indicated that a permeability control mechanism was affected by chilling; such a mechanism would presumably be located in the cytoplasmic membrane. The known stabilizing effect of magnesium ions on isolated protoplast membranes (Weibull, 1956) and spheroplasts (Lederberg, 1956; McQuillen, 1958) 
suggested that metal ions might protect bacteria during cold shock. The effect of adding magnesium and other divalent metals to the diluent in which bacteria were chilled was investigated. Bacteria suspended in buffered saline or tris buffer were substantially protected during chilling in the presence of $\mathrm{Mg}^{2+}, \mathrm{Ca}^{2+}$ or $\mathbf{M n}^{2+}$ (Table 2; Fig. 9). With distilled water as the diluent, $\mathrm{Mn}^{2+}$ was slightly toxic, $\mathrm{Ca}^{2+}$ or $\mathrm{Mg}^{2+}$ had little effect and $\mathrm{Co}^{2+}, \mathrm{Zn}^{2+}$ or $\mathrm{Fe}^{2+}$ were very toxic (Table 2). The pH value of suspensions in distilled water was decreased by the presence of metals; this may have contributed to the loss of viability which occurred.

Sucrose and erythritol. Meynell (1958) showed that exponential-phase Escherichia coli suspensions were protected during chilling by sucrose (0.3 M). Chilled Aerobacter

\section{Table 2. Effect of divalent metal ions on the loss of viability of exponential-phase}

Aerobacter aerogenes suspensions at $0^{\circ}$

Bacteria, separated from the culture by centrifugation, were diluted to about $10^{8} / \mathrm{ml}$. in various diluents.

\begin{tabular}{|c|c|c|c|}
\hline $\begin{array}{l}\text { Bac- } \\
\text { teria } \\
\text { batch } \\
\text { no. }\end{array}$ & Diluent & Addition to diluent & $\begin{array}{c}\% \text { viability of } \\
\text { suspension } \\
\text { after } 45 \text { min. } \\
\text { at } 0^{\circ}\end{array}$ \\
\hline 1 & buffered saline (pH 6.5) & $\begin{array}{c}\text { nil } \\
\mathrm{MgSO}_{4}: 0 \cdot 5,1 \cdot 0,5 \cdot 0 \mathrm{mM} \\
* \mathrm{MnSO}_{4}: 0 \cdot 5,1 \cdot 0,5 \cdot 0 \mathrm{mM} \\
\mathrm{CaCl}_{2}: 0 \cdot 5,1 \cdot 0,5 \cdot 0 \mathrm{mM}\end{array}$ & $\begin{array}{r}10 \\
19,16,53 \\
7,8,84 \\
10,16,71\end{array}$ \\
\hline 2 & $0 \cdot 05$ m-tris buffer $(\mathrm{pH} 7 \cdot 5)$ & $\left\{\begin{array}{l}\quad \text { nil } \\
\mathrm{MgSO}_{4}, 5 \mathrm{~mm} \\
\mathrm{MnSO}_{4}, 5 \mathrm{~mm} \\
\mathrm{CaCl}_{2}, 5 \mathrm{~mm}\end{array}\right.$ & $\begin{array}{l}<1 \\
94 \\
74 \\
88\end{array}$ \\
\hline $\mathbf{3}$ & distilled water & $\begin{array}{c}\text { nil } \\
\mathrm{MgSO}_{4}: 1 \cdot 0,2 \cdot 5,5 \cdot 0 \mathrm{~mm} \\
\mathrm{MnSO}_{4}: 1 \cdot 0,2 \cdot 5,5 \cdot 0 \mathrm{~mm} \\
\mathrm{CaCl}_{2}: 1 \cdot 0,2 \cdot 5,5 \cdot 0 \mathrm{~mm} \\
\mathrm{CoSO}_{4}: 1 \cdot 0,2 \cdot 5,5 \cdot 0 \mathrm{~mm} \\
\mathrm{ZnSO}_{4}: 1 \cdot 0,2 \cdot 5,5 \cdot 0 \mathrm{~mm} \\
\mathrm{FeSO}_{4}: 1 \cdot 0,2 \cdot 5,5 \cdot 0 \mathrm{~mm}\end{array}$ & $\begin{aligned} & 85 \\
& 76,79,83 \\
& 28,37,57 \\
& 88,81,91 \\
< & 1 \\
< & 1 \\
< & 1\end{aligned}$ \\
\hline
\end{tabular}

* Precipitation occurred when $\mathrm{Mn}^{2+}$ was added to this diluent.

aerogenes suspensions were also protected by sucrose (Fig. 10). Analysis of filtrates of chilled bacterial suspensions in buffered saline with and without sucrose $(0.3 \mathrm{M})$ showed that the concentration of leakage products was considerably less in the presence of sucrose. This sugar does not penetrate into $A$. aerogenes whereas I-erythritol does (Postgate \& Hunter, 1961). When bacteria were chilled in buffered saline, buffered saline + sucrose $(0 \cdot 3 \mathrm{M})$ and buffered saline + erythritol $(0 \cdot 3 \mathrm{M})$, losses of viability after $1 \mathrm{hr}$. at $0^{\circ}$ were 99,24 and $88 \%$, respectively.

Spermine. Since spermine $\left(10^{-3} \mathrm{M}\right)$ stabilizes Pasteurella tularensis and Escherichia coli spheroplasts against osmotic damage (Mager, 1959) it was possible that this substance might protect bacteria during cold shock. At $0^{\circ}$, the loss of viability of exponential-phase Aerobacter aerogenes in buffered saline containing $10^{-3} \mathrm{M}$ spermine was more rapid than in buffered saline alone. In the presence of $10^{-5} \mathrm{M}$ spermine there was a transient protective effect: losses of viability after 10, 20 and $30 \mathrm{~min}$. at 
$0^{\circ}$ were 34, 65 and $75 \%$, respectively, as compared with 78,82 and $86 \%$, respectively, in the control suspension.

\section{Revival of chilled bacteria}

Protective substances which appeared to exert their influence on bacteria during chilling may have in fact acted after chilling, by reviving moribund bacteria so that they were able to grow on nutrient agar. When bacterial suspensions in buffered saline were chilled and then amino acids, magnesium, calcium or manganese added, viability was not affected. However, when leakage products from a chilled con-

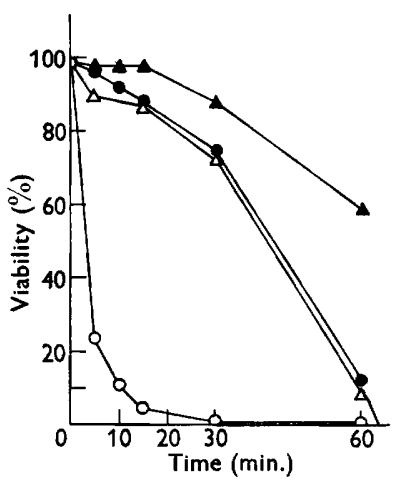

Fig. 8

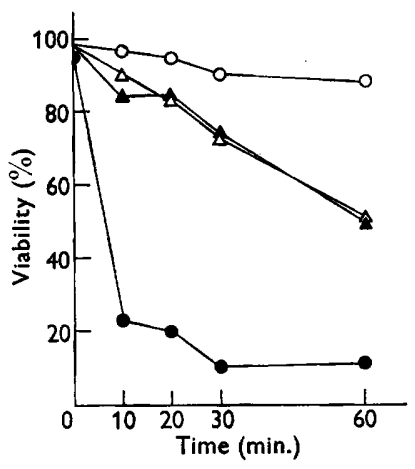

Fig. 9

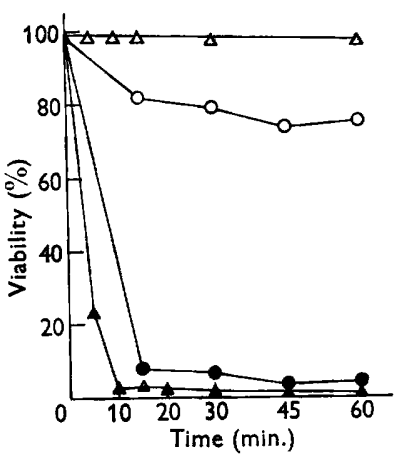

Fig. 10

Fig. 8. Influence of leakage products from chilled bacteria and amino acid mixtures on the survival of exponential phase Aerobacter aerogenes at $0^{\circ}$. Bacteria separated from the culture were diluted to about $10^{8} / \mathrm{ml}$. in the solutions given held at $0^{\circ}$. Viability in filtrate $(\Delta)$, in amino acid mixture $A(\triangle)$, in amino acid mixture $B(\odot)$ and in buffered saline (O). The filtrate was prepared from a suspension of chilled exponential phase organisms in buffered saline $\left(1.3 \times 10^{10} / \mathrm{ml}\right.$.). Mixture A contained $0.5 \mathrm{~mm}$ each of the 10 amino acids (L-isomers) found in leakage products (see text) dissolved in buffered saline; mixture $B$ contained amino acids in $A+0.5 \mathrm{~mm}$ each of tyrosine, phenylalanine, lysine, $\alpha, \epsilon$-diaminopimelic acid (meso), threonine (DL), cystine and tryptophan.

Fig. 9. Influence of divalent metal ions on the survival of exponential Aerobacter aerogenes at $0^{\circ}$. Viability of suspensions (about $10^{8}$ bacteria $/ \mathrm{ml}$.) in tris buffer containing: $5 \mathrm{~mm}$ $\mathrm{MgSO}_{4}(\mathrm{O}), 5 \mathrm{~mm}-\mathrm{CaCl}_{2}(\triangle), 5 \mathrm{~mm}-\mathrm{MnSO}_{4}(\Delta)$; viability in tris buffer control (O).

Fig. 10. Influence of sucrose on the survival of exponential phase Aerobacter aerogenes at $0^{\circ}$. Bacteria separated from two separate cultures were diluted to about $10^{8} / \mathrm{ml}$. in diluents at $0^{\circ}$. Viability in buffered saline containing $0.3 \mathrm{~m}$ sucrose $(0, \Delta)$, in buffered saline control $(\boldsymbol{O}, \Delta)$.

centrated suspension were added to a dilute chilled suspension, the viability increased. A suspension of Aerobacter aerogenes in buffered saline $\left(3 \times 10^{8}\right.$ bacteria $/ \mathrm{ml}$.) was held at $0^{\circ}$ and samples, removed at intervals, were diluted with an equal volume of either buffered saline or filtrate from chilled $\left(1 \mathrm{hr} ., 0^{\circ}\right)$ exponential-phase bacteria in buffered saline $\left(3 \times 10^{10} / \mathrm{ml}\right.$.). Viabilities, determined immediately after dilution with buffered saline, of bacteria held at $0^{\circ}$ for 15,30 and $60 \mathrm{~min}$. were 39 , 23 and $15 \%$, respectively; after dilution with filtrate, the viabilities of the samples were 76, 72 and $35 \%$, respectively. On chilling similar concentrations of these bacteria in equal volumes of buffered saline and filtrate, viabilities after the same periods at $0^{\circ}$ were 98,92 , and $89 \%$, respectively. Thus, the protective effect of leakage products exerted during chilling was greater than the revival effect which 
these substances exerted on chilled bacteria. The revival effect was not due to transfer of leakage products with bacteria onto slide cultures; in experiments where the viability was determined by viable counts involving a $1 / 10^{5}$ dilution of the sample before plating, an increase in the viability of a chilled suspension occurred after the addition of leakage products.

\section{DISCUSSION}

The effect of the growth phase on the susceptibility of dilute Aerobacter aerogenes suspensions to cold shock was similar to that found with Escherichia coli (Sherman \& Albus, 1923; Sherman \& Cameron, 1934; Hegarty \& Weeks, 1940; Meynell, 1958) and Pseudomonas pyocyanea (Gorrill \& McNeil, 1960). Also, as previously found, the lethal effect of cold shock depended on the diluent. However, with exponentialphase $A$. aerogenes the lethal effect was less in distilled water than in buffered saline or tris buffer, whereas with growing $\boldsymbol{P}$. pyocyanea it was greater in distilled water than in Ringer's solution, buffer solution or saline (Gorrill \& McNeil, 1960). In this connexion, it is of interest that the death rate of steadily growing $A$. aerogenes caused by freezing in liquid nitrogen was less with suspensions in distilled water than with those in saline phosphate or saline tris buffers (Postgate \& Hunter, 1961).

The finding that a rapid leakage of endogenous constituents occurs on chilling bacteria supports the view that the lethal effect of cold shock is due to interference with a bacterial permeability control mechanism (Meynell, 1958). The population density phenomenon, and the protective effect that filtrates of dense populations exert on the survival of sparser populations, together imply that one or more of these leakage products is necessary for their survival and can be resorbed by the bacteria from their external environment. This resorption must be a rapid process, since brief exposure of moribund populations in buffered saline to leakage products from a denser population increased their viability. This reactivation phenomenon was not only observed when viability was determined by slide culture but also in experiments where viability was determined by a plate counting technique involving a $1 / 10^{5}$ dilution of the suspension. The protective material clearly induced a permanent change in the population; one no longer influenced by dilution.

Our experiments show that during chilling the protective activity of leakage products may be partially due to the presence of amino acids; ATP was also leaked but it was inactive when added to diluents in which bacteria were chilled. Other substances which protected bacteria but which were not detected or are unlikely to be constituents of leakage products are calcium, magnesium, manganese and sucrose. The mechanisms by which these substances protect during cold shock are probably different from the one which operates with leakage products or amino acids. The known stabilizing effect of magnesium on isolated protoplast membranes (Weibull, 1956) and spheroplasts (Lederberg, 1956; McQuillen, 1958) suggests that the metal ions decrease the permeability of the cytoplasmic membrane in the intact cell during chilling. The protective influence of sucrose shown previously with Escherichia coli by Meynell (1958) is probably due to its osmotic activity which causes a decrease in the rate of diffusion of constituents out of bacteria. Erythritol in equivalent concentration did not have a similar protective effect, presumably because this substance is osmotically neutral with Aerobacter aerogenes (Postgate \& Hunter, 1961). 
Despiteits reported stabilizing effect on $E$ scherichia coli spheroplasts against osmotic shock (Mager, 1959), low concentrations of spermine had only a transient protective effect on chilled Aerobacter aerogenes. However, higher concentrations of spermine were toxic to chilled organisms and the losses of viability which occurred with lower concentrations of the substance may have been due to this toxic effect as well as to cold shock.

We thank Dr J. R. Postgate for helpful criticism and suggestions, Mr A. G. Ness for some of the analyses, Mr S. Lovett for the use of a scintillation counter and Mr B. Phillips for technical assistance.

\section{REFERENCES}

Gorrill, R. H. \& McNeIL, E. M. (1960). The effect of cold diluent on the viable count of Pseudomonas pyocyanea. J. gen. Microbiol. 22, 437.

Hegarty, C. P. \& Weers, O. B. (1940). Sensitivity of Escherichia coli to cold-shock during the logarithmic growth phase. J. Bact. 39, 475.

LeDerberg, J. (1956). Bacterial protoplasts induced by penicillin. Proc. nat. Acad. Sci., Wash. 42, 574.

Levine, R. M. \& Cummings, J. R. (1956). A sensitive, accurate spectrophotometric method for the determination of magnesium in serum. J. biol. Chem. 221, 735 .

McNaIr ScotT, D. B. \& CHU, E. (1958). Synchronised division of growing cultures of Escherichia coli. Exp. Cell Res. 14, 166.

McQuillen, K. (1958). Lysis resulting from metabolic disturbances. J. gen. Microbiol. 18, 498.

MAGER, J. (1959). The stabilising effect of spermine and related polyamines on bacterial protoplasts. Biochim. biophys. acta, 36, 529.

Meyneld, G. G. (1958). The effect of sudden chilling on Escherichia coli. J. gen. Microbiol. 19, 380.

Postgate, J. R., Crumpton, J. E. \& Hunter, J. R. (1961). The measurement of bacterial viabilities by slide culture. J. gen. Microbiol. 24, 15 .

Postgate, J. R. \& Hunter, J. R. (1961). On the survival of frozen bacteria. J. gen. Microbiol. 26, 367.

Sherman, J. M. \& Albus, W. R. (1923). Physiological Youth in bacteria. J. Bact. 8, 127.

Sherman, J. M. \& Cameron, G. M. (1934). Lethal environmental factors within the natural range of growth. J. Bact. 27, 341.

Strange, R. E., Dark, F. A. \& Ness, A. G. (1961). The survival of stationary phase Aerobacter aerogenes stored in aqueous suspension. J. gen. Microbiol. 25, 61.

Strenter, B. L. \& Totter, J. R. (1952). Firefly luminescence in the study of energy transfer mechanisms. I. Substrate and enzyme determination. Arch. Biochem. Biophys. 40, 28.

WEIBULL, C. (1956). Bacterial protoplasts; their formation and characteristics. In Bacterial Anatomy, Symp. Soc. gen. Microbiol. 6, 111.

Yemm, E. W. \& Cocking, E. C. (1955). The determination of amino-acids with ninhydrin. Analyst, 80, 209. 